\section{Nauplius}

The Journal of The

Brazilian Crustacean Society

e-ISSN 2358-2936

www.scielo.br/nau www.crustacea.org.br

\title{
New records of Cladocera (Crustacea: Branchiopoda) from the Tomo River, Vichada, Colombia
}

Juan M. Fuentes-Reinés ${ }^{1}$ (D) orcid.org/0000-0001-5809-4271

Lourdes M.A. Elmoor-Loureiro ${ }^{2}$ (D) orcid.org/0000-0001-7439-9753

Cristian E. Granados-Martínez ${ }^{3}$

1 Universidad del Magdalena, Grupo de investigación en Biodiversidad y Ecología Aplicada. Santa Marta, Colombia. AA 731.

2 Universidade Católica de Brasília - UCB, Laboratório de Biodiversidade Aquática. QS 7, Lote 1, Bloco M, sala 204. 71966-700 Taguatinga, Distrito Federal, Brazil.

3 Universidad de la Guajira, Grupo de investigación de Ecología-Biodiversidad en ecosistemas tropicales. Riohacha, Kilometro 5, Vía Maicao. La Guajira, Colombia.

ZOOBANK http://zoobank.org/urn:lsid:zoobank.org:pub:02BA492E-AC28-464EA721-C8A10D0E85AE

\section{Abstract}

Five species of cladocerans are reported from the Tomo River, Vichada, Colombia. Zooplankton samples were collected from the littoral zone with vegetation (Campsiandra comosa Benth). Three of them, namely Streblocerus pygmaeus Sars, 1901, Disparalona cf. hamata (Birge, 1879) and Alona isabellae Sousa, Elmoor-Loureiro and Santos, 2016 are new to the Colombian cladoceran fauna. Descriptive notes, comparative comments on morphology and variability and illustrations are also provided for some remarkable taxa. This is the first report on the cladoceran fauna in the Tomo River.

\section{KEY WORDS}

Cladocera, taxonomy, new records, Neotropical region, geographic distribution.

\section{INTRODUCTION}

Cladocera is one of the main zooplankton groups which inhabits fresh,

CORRESPONDING AUTHOR Juan M. Fuentes-Reinés juanfuentesreines@gmail.com

SUBMITTED 01 July 2017 ACCEPTED 18 November 2017 PUBLISHED 15 March 2018

DOI 10.1590/2358-2936e2018006

\section{(cc) BY}

All content of the journal, except where identified, is licensed under a Creative Commons attribution-type BY. Nauplius, 26: e2018006 
Fuentes-Reinés (2015b) reported 101 valid species of Cladocera for Colombia; nevertheless, this number could increase because only 19 departments among 31 have records of this group.

During the scientific expedition "Vichada BIO" in 2017, some zooplankton samples were taken in the lower part of the Tomo River, located in the Orinoco region. The Tomo River is a tributary of the Orinoco River; the head of the river is located in the Meta department and crosses the Vichada department. Hitherto, there have been no single records of cladocerans in this system.

Based on samples collected from littoral habitats, we found several interesting taxa of Cladocera dwelling in the Tomo River. Descriptive notes, comparative comments on morphology and variability, and illustrations are also provided for some remarkable taxa. This work contributes to increasing the knowledge of this group in Colombia and the Neotropical region.

\section{Material and Methods}

Four samples were collected in the littoral zone among the roots of Campsiandra comosa Benth in the lower part of the Tomo River $\left(05^{\circ} 48^{\prime} 02.5^{\prime \prime} \mathrm{N}\right.$ $\left.68^{\circ} 13^{\prime} 19.8^{\prime \prime} \mathrm{W}\right)$, in April 2017. Water $\mathrm{pH}$ and temperature were measured with a multiparameter WTW 350i. Two hundred and eighty-eight (288) liters of water were taken using a 25 -L bucket, then filtered through a zooplankton net $(45 \mu \mathrm{m})$ and preserved in $70 \%$ ethanol. Samples were stained with bengal rose. The filtered samples were concentrated to $50 \mathrm{ml}$ and, with a Bogorov counting chamber, cladocerans were sorted and the obtained specimens were measured in lateral position from the anterior-most extremity of the rostral area to the posterior margin of the valve. Cladocerans were dissected and their appendages were mounted on slides with glycerin and sealed with Canada balsam; then, appendages were photographed using a Kodak Easy Share C140 digital camera adapted to a compound microscope. The specimens examined were deposited at the Museo de Colecciones Biológicas de la Universidad del Atlántico, Barranquilla-Atlántico, Colombia (Universidad del Atlántico Región Caribe UARC), where they are available for consultation and/ or further examination. The identification of the species followed Smirnov (1992; 1996), Fuentes-Reinés et al. (2012), and Sousa et al. (2016).

\section{ResULTS}

The taxonomic analysis of the cladoceran specimens collected yielded the identification of five species belonging to two families and five genera. The family Chydoridae showed the highest species richness (3) (Tab. 1). These are all new records for the Tomo River. Brief remarks, descriptions and illustrations about the relevant species are given below.

\section{Family Macrothricidae Norman \& Brady, 1867 emend. Dumont \& Silva-Briano, 1998}

\section{Genus Macrothrix Baird, 1843}

\section{Macrothrix spinosa (King, 1853)}

Synonymy. Macrothrix goeldi Richard, 1897; Macrothrix squamosa Sars, 1901; Macrothrix affinis Brady, 1904 in Fuentes-Reinés et al. (2012): 130.

\section{Material examined. 2 adult females, UARC327M.}

Remarks. Macrothrix spinosa was the least abundant species among Macrothricidae in the samples and was originally described from Australia by King (1853). It is similar to its Neotropical congener M. squamosa; therefore, the latter species was accepted as a synonym of $M$. spinosa. This synonymy is based on the similarity of general characteristics, for example the general aspect of the valve, antennule, and postabdomen (ElmoorLoureiro, 2007). Taking into consideration the concept of non-cosmopolitanism in cladocerans given by Frey (1982), it is possible that M. spinosa and M. squamosa constitute separate species; nevertheless, an exhaustive revision is required.

Machrotrix spinosa is easily identifiable by its oval body, antennule dilating distally, and the serrations along the dorsal part of the valve (see Fuentes-Reinés and Elmoor-Loureiro, 2015b).

Distribution. It occurs in the tropical and subtropical territories of the world (Smirnov, 1992); it seems to have a broad distribution in Colombia, and is recorded in the Caribbean region (Kotov and Fuentes-Reinés, 2015b). This is the first record from the Orinoco region. 
Table 1. Species of Cladocera from the Tomo River (Colombia) and their distribution. Geographic category: NT (Neotropical), C (Cosmopolitan), NA (Nearctic), OR (Oriental), PAN (Pantropical). Departments: At (Atlántico), Co (Córdoba), Gu (La Guajira), Sa (Santander), Mg (Magdalena), $\mathrm{Vi}$ (Vichada). * New record for the Vichada department; ${ }^{* *}$ New record for Colombia.

\begin{tabular}{|c|c|c|c|c|}
\hline Family & Taxon & World distribution & $\begin{array}{c}\text { Distribution in } \\
\text { Colombia }\end{array}$ & References to Colombia \\
\hline \multirow[t]{2}{*}{ Macrothricidae } & Macrothrix spinosa* & PAN & At, $\mathrm{Co}, \mathrm{Mg}, \mathrm{Gu}, \mathrm{Vi}$ & $\begin{array}{l}\text { Álvarez (2010); } \\
\text { Fuentes-Reines et al. (2012); } \\
\text { Fuentes-Reines (2014a); } \\
\text { present paper }\end{array}$ \\
\hline & Streblocerus pygmaeus ${ }^{* *}$ & NT, NA, OR & $\mathrm{Vi}$ & Present paper \\
\hline Chydoridae: Aloninae & Alona isabellae ${ }^{* *}$ & NT & $\mathrm{Vi}$ & Present paper \\
\hline \multirow[t]{2}{*}{ Chydoridae: Chidorinae } & Alonella dadayi* & NT, NA & $\mathrm{Sa}, \mathrm{Co}, \mathrm{Mg}, \mathrm{Vi}$ & $\begin{array}{l}\text { Barón-Rodríguez et al. (2006); } \\
\text { Álvarez (2010); } \\
\text { Fuentes-Reinés et al. (2012); } \\
\text { present paper }\end{array}$ \\
\hline & Disparalona cf. hamata** & $\mathrm{C}$ & $\mathrm{Vi}$ & Present paper \\
\hline
\end{tabular}

Genus Streblocerus Sars, 1862

\section{Streblocerus pygmaeus Sars, 1901}

Material examined. 5 adult females, UARC326M.

Remarks. It was one of the most abundant species in the samples. Its body is globular in lateral view, with convolute intestine (Fig. 1A) and divergent antennules (Fig. 1B). It can be differentiated from its congeners by the postabdomen, which bears setae in the preanal marginal portion (Fig. 1C) instead of spines; these setae form distinct groups (Fig. 1D), as observed also in populations from Mexico, the U.S.A. and Brazil (Smirnov, 1992; Garfia-Espejo and Elías-Gutierrez, 2003), although they are not grouped in the population from the Nhamundá River (Smirnov, 1992). Body length is between 0.21 and $22 \mathrm{~mm}$, average: $0.22 \mathrm{~mm}$ $(\mathrm{n}=5)$.

Distribution. It has been recorded in the Neotropical, Nearctic and Oriental regions (Kotov et al., 2013); nevertheless, the population from China recorded by Chian and $\mathrm{Du}$ (1979) is considered to be a doubtful identification (Smirnov, 1992). This is the first record from the Orinoco region and Colombia.
Family Chydoridae Dybowski et Grochowski, 1894 emend. Frey 1967

\section{Subfamily Aloninae Dybowsky \& Grochowski, 1894 emend. Frey, 1967}

\section{Genus Alona Baird, 1843}

\section{Alona isabellae Sousa, Elmoor-Loureiro and Santos, 2016}

Synonymy. See Sousa et al. (2016): 23.

Material examined. 2 adult females, UARC316MUARC320M.

Remarks. Alona isabellae was originally described by Sousa et al. (2016) based on specimens previously identified as Alona intermedia Sars, 1862 in Brazil (see Sousa et al., 2016). Its body is oval (Fig. 1E), maximum height at middle of body, body height/ length ratio about $0.63 \mu \mathrm{m}$, body length $=0.27 \mathrm{~mm}$, average: $0.27 \mathrm{~mm}(\mathrm{n}=2)$, head with two major pores connected (Fig. 1F), postabdomen about 2.6 times as long as wide (Fig. 2A), with nine lateral fascicles and ten postanal marginal denticles. IDL and ODL 

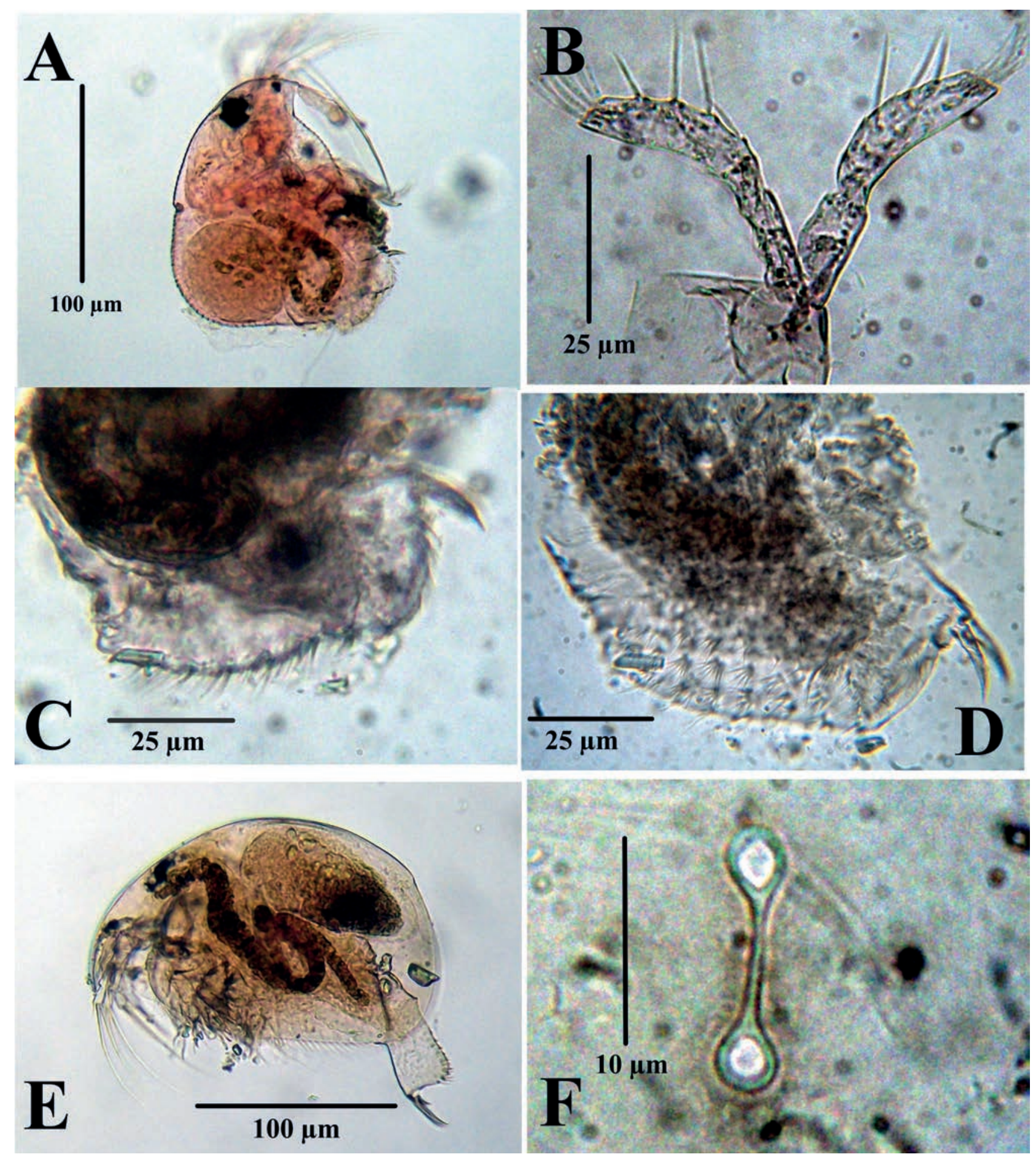

Figure 1. Stroblocerus pygmaeus Sars, 1901, adult female from the Tomo River, Colombia. A, Adult; B, antennule; C, D, postabdomen. Alona isabellae Sousa, Elmoor-Loureiro and Santos, 2016, adult female. E, Adult, F, head pores.

of limb I with three and one setae respectively. Limb II with inner portion armed with eight scrapers, first and second ones different in size.

Alona isabellae can be easily separated from other members of the Alona intermedia-group by the peculiarities of the spinule of distalmost fascicles, which is thicker than the others and goes beyond the postabdomen margin and the marginal denticles (arrowed in Fig. 2A, B). Another important diagnostic feature is the labrum with two short and fine spinules on the anterior margin and a cluster of setules on the posterior margin (Fig. 2C). These two distinctive 

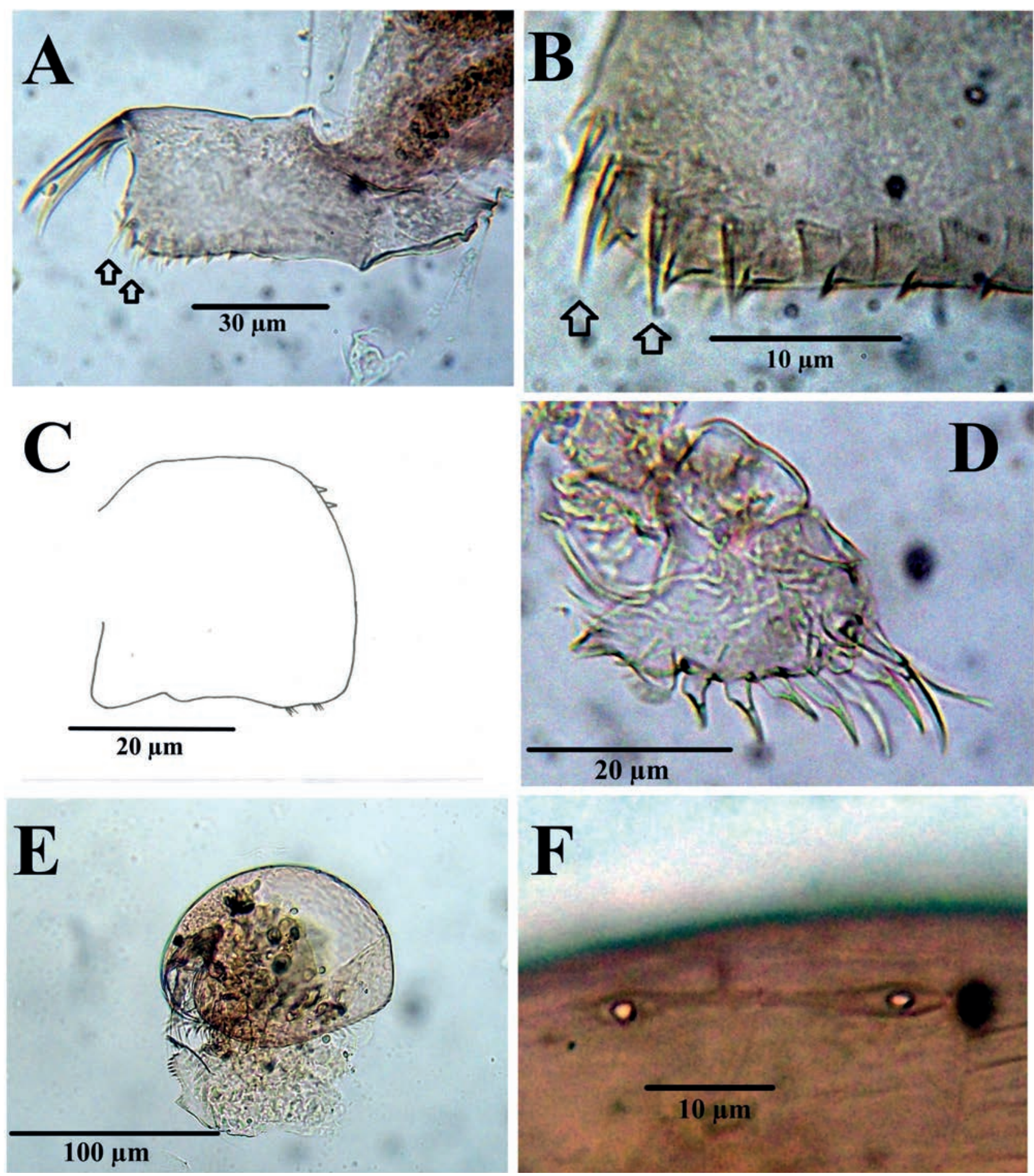

Figure 2. Alona isabellae Sousa, Elmoor-Loureiro and Santos, 2016, adult female from the Tomo River. A, Postabdomen; B, distal portion of postabdomen; C, labrum; D, limb II. Alonella dadayi Birge, 1910, adult female. E, Adult; F, head pores.

characters are present in the Colombian specimens.

The specimens from Colombia have diagnostic features of $A$. isabellae as described by Sousa et al. (2016). There are, however, some small differences in our specimens: (1) proximal and distal denticles of the postabdomen with fine spinules in the populations from Brazil (Sousa et al., 2016, fig. 7O), while in Colombian populations this structure is only absent in distal denticles (Fig. 2B, present data); (2) scraper 4 and 5 of limb II different in length in specimens from Colombia (Fig. 2D), while they are of the same size in Brazilian populations (Sousa et al., 2016, fig. 8F). 

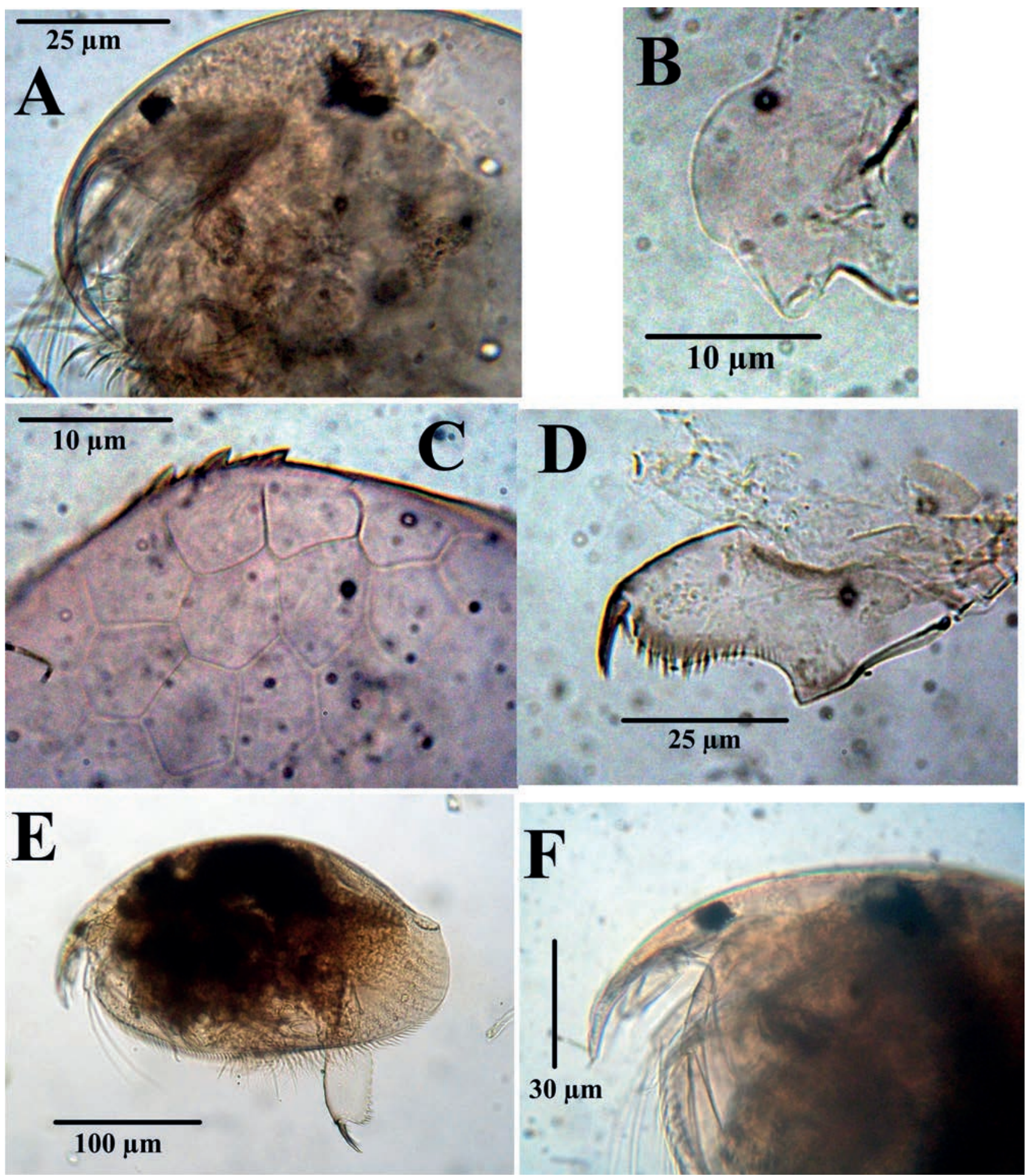

Figure 3. Alonella dadayi Birge, 1910, adult female from the Tomo River. A, rostrum; B, labrum; C, valve; D, postabdomen. Disparalona cf. hamata (Birge, 1879), adult female. E, Adult; F, Rostrum.

Overall, these differences are deemed to be intraspecific variations and thus expand the knowledge on the morphometric variability of this species.

Distribution. Alona isabellae is so far known only from Brazil (Sousa et al., 2016) and Colombia (present study). Some records of $A$. intermedia have been recorded from Venezuela, Peru, and Paraguay (Daday, 1905; Stingelin, 1906; Delachaux, 1918; Rey and Vazquez, 1986), and these reports could correspond to $A$. isabellae or to a new species; nevertheless, an exhaustive review of these records is required. 

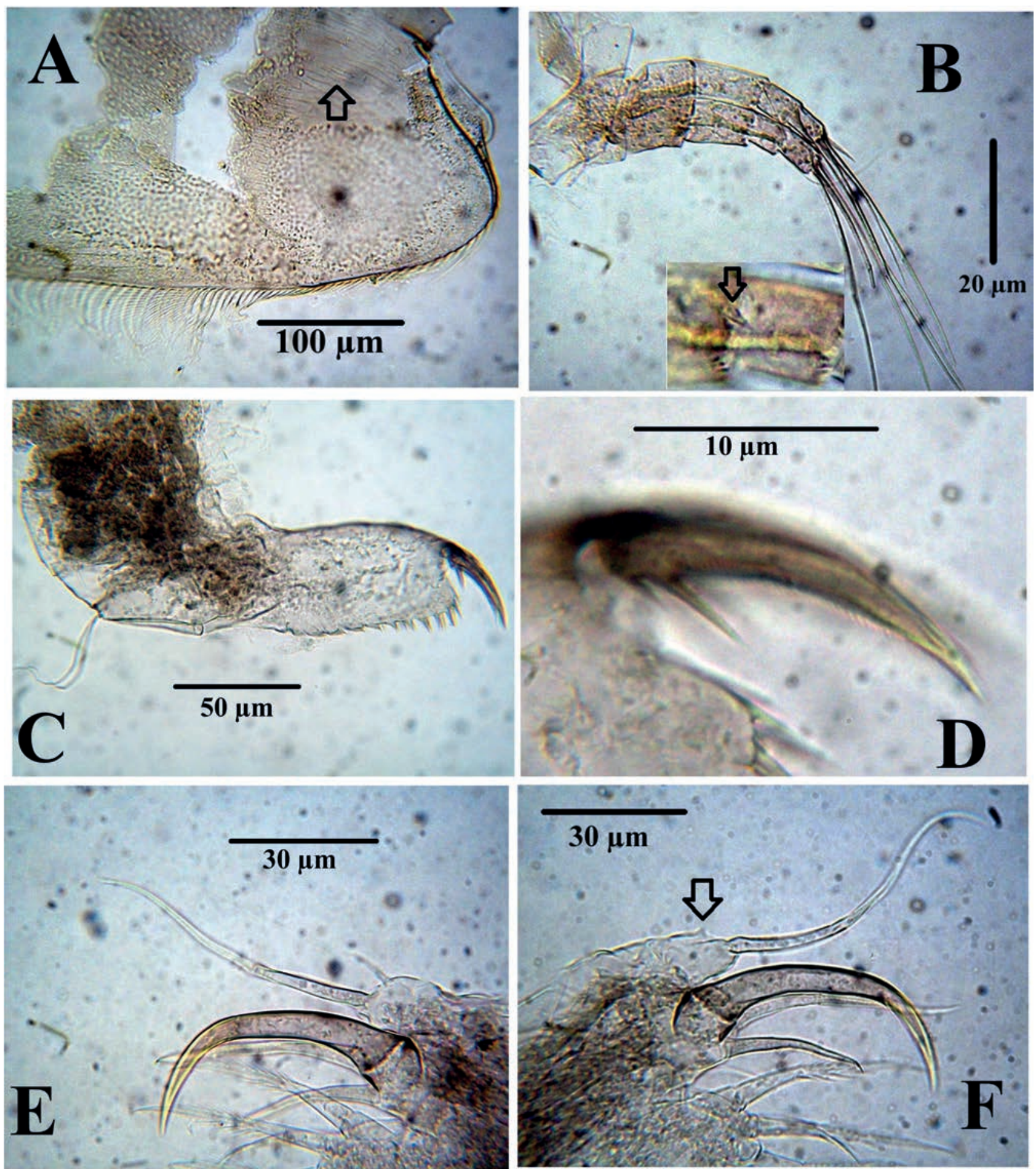

Figure 4. Disparalona cf. hamata (Birge, 1879), adult female from the Tomo River. A, Valves; B, antenna; C, postabdomen; D, postabdominal claw; E, F, IDL of limb I.

Subfamily Chydorinae Dybowski \& Grochowski, 1894 emend. Frey, 1967

\section{Genus Alonella Sars, 1862}

Alonella dadayi Birge, 1910
Synonymy. See Smirnov (1996): 88.

Material examined. 5 adult females, UARC328M.

Remarks. The specimens from Colombia share the diagnostic features of $A$. dadayi previously reported 
from the Magdalena department (Fuentes-Reinés et al., 2012). Oval body (Fig. 2E), with two major head pores of equal size (Fig. $2 \mathrm{~F}$ ), rostrum long and curved (Fig. 3A) valve with three denticles on the posterior ventral angle (Fig. 3C). Body length $=0.19-0.23 \mathrm{~mm}$, average: $0.22 \mathrm{~mm}(\mathrm{n}=5)$. It can be easily distinguished from its congeners by (1) the long and downwardspointing rostrum (Fig. 3A); (2) wavy anterior margin of labral keel (Fig. 3B); (3) the reticulation patterns of valve which are regular polygons at the posteral ventral angle (Fig. 3C); (4) short postabdomen with 8-9 sharp teeth along its margin; (5) prominent preanal angle of postabdomen (Fig. 3D).

Distribution. This species has been recorded from the North to South America (Smirnov, 1996; Van Damme and Dumont, 2010). In Colombia, A. dadayi has been reported in Caribbean and Andean regions (Kotov and Fuentes-Reinés, 2015b). This is the first record for the Orinoco region.

\section{Genus Disparalona Fryer, 1968}

\section{Disparalona cf. hamata (Birge, 1879)}

Material examined. 1 adult female, catalog number: UARC321M-UARC325M.

Remarks. Eight valid species of the genus Disparolona have been described worldwide: Disparolona rostrata (Koch, 1841), Disparolona acutirostris (Birge, 1879); D. hamata; Disparolona leei (Chien Shing-ming, 1970); Disparolona caudata Smirnov, 1996; Disparolona leptorhyncha Smirnov, 1996; Disparolona ikarus Kotov and Sinev, 2011 and Disparolona smirnovi Klimovsky, 2015. Of these, D. leptorhyncha and D. hamata have been recorded in the Neotropics, and the latter was originally described as Pleuroxus hamatus by Birge (1879) from North America; however, Smirnov (1996) allocated the species to the genus Disparalona.

The specimen from Colombia has an elongated body, and the posterior portion of body is remarkable lower than the anterior (Fig. 3E), short rostrum (Fig. $3 \mathrm{~F}$ ), and valve with fine striae (arrowed in Fig. 4A). Antenna of moderate size (Fig. 4B), the proximal segments of each branch are twice as long as and more massive than the other two, antennal formula: setae
0-0-3/0-1-3, first endopodal segment with a small spine (arrowed in Fig. 4B). Keel not prominent, distal portion short and rounded. Postabdomen about 3.4 times as long as wide, with preanal angle not prominent (Fig. 4C); postabdominal claw with two basal spines, the distal about 0.25 the length of the claw and the proximal two times shorter than the proximal one (Fig. 4D). IDL of limb I with three setae, the seta 3 is hook-like (Fig. 4E, F), ODL with one long and one short accessory seta, the outer one very short (Fig. 4E) which was variable in size (arrowed in Fig. 4F). Limb II with eight scrapers, the seta of exopodite is longer than scrapers 8, 7,6 and 4 (Fig. 5A). Exopodite of limb III is rectangular, with two lateral setae (56) and four distal setae (1-4) (Fig. 5B); seta 7 was not observed and, taking into account that only one specimen was examined, it is probable that it could be due to variability or it could have been broken. Nevertheless, more specimens should be examined and observed to confirm it. The exopodite of limb IV is oval with seven setae (1-7) (Fig. 5C). Epipodite of limb V ovoid; exopodite with two hillocks densely setulated near the inner limb portion (arrowed in Fig. 5E) and a single distal (1) and three lateral (2-4) setae (Fig. 5D, E); inner limb portion elongated (Fig. 5F), with setulated inner margin, with two setae of equal size; filter comb with three setae.

The specimen from Colombia bears the diagnostic features of $D$. hamata reported by the authors based on the study of material from Venezuela, Brazil, Sudan and Mali (Rey and Vásquez, 1986; Zoppi de Roa and Vásquez, 1991; Smirnov, 1996; Elmoor-Loureiro, 1997). However, some subtle differences can be observed in our specimen: (1) the outer small seta of the ODL of limb I is absent in figures of specimens from Venezuela (Rey and Vásquez, 1986, pl. V, fig. 14; Zoppi de Roa and Vásquez, 1991, fig. 10B), whereas it is present in populations from Colombia (present data, Fig. 4D, E); (2) the exopodite of limb IV bears seven setae in specimens from Colombia (present data, Fig. 5B), whereas populations from Venezuela have six (Zoppi de Roa and Vásquez, 1991, fig. 10I), and probably these two structures were overlooked in specimens from Venezuela owing to their size. Unfortunately, Smirnov (1996) and Elmoor-Loureiro (1997) did not illustrate these structures, making comparisons impossible. 

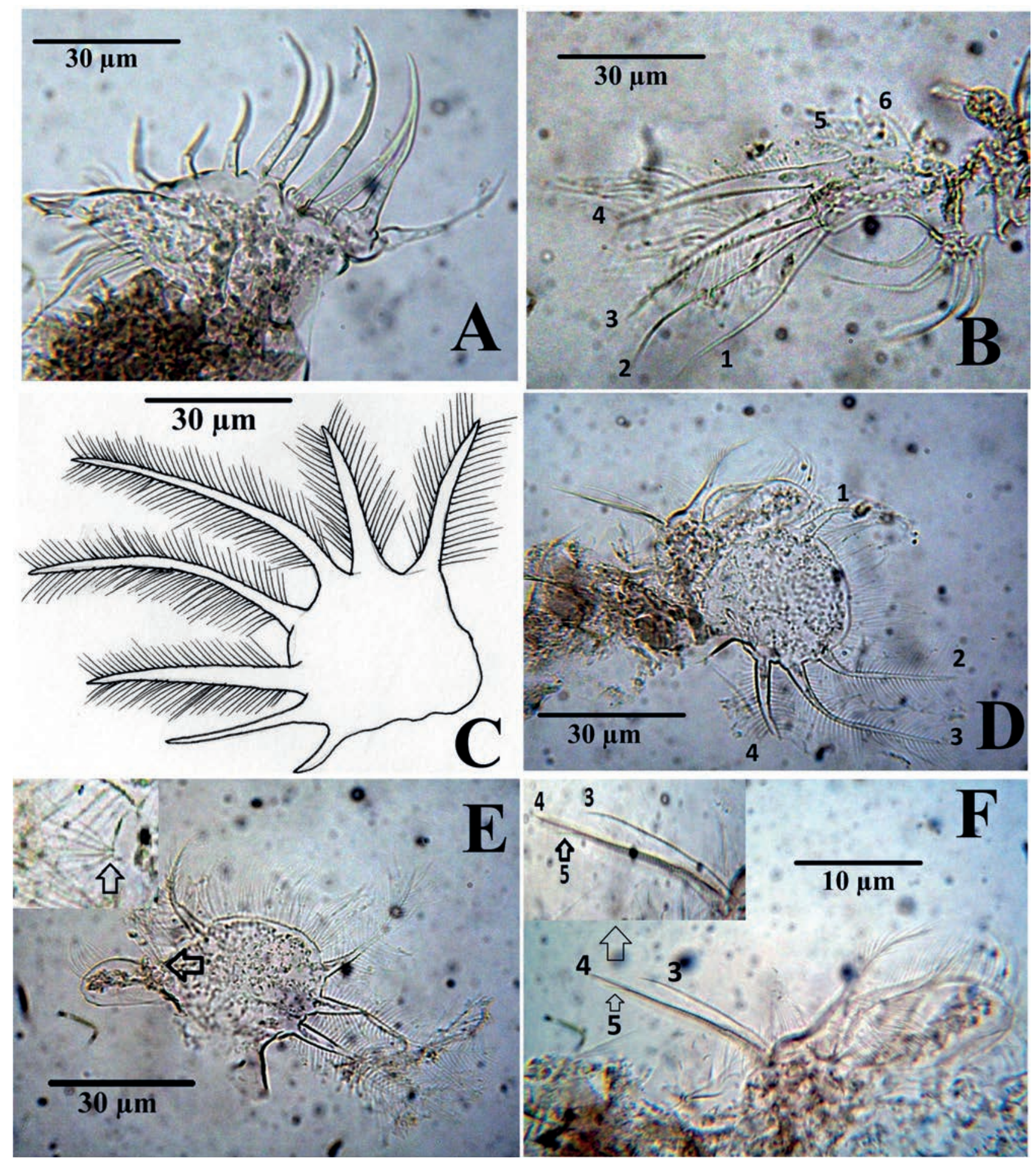

Figure 5. Disparalona cf. hamata (Birge, 1879), adult female from the Tomo River. A, Limb II; B, exopodite of limb III; C, exopodite of limb IV; D, E, limb V; F, limb V, inner portion.

Disparalona hamata has been poorly described (Birge, 1879; Rey and Vásquez, 1986; Zoppi de Roa and Vásquez, 1991; Smirnov, 1996; Elmoor-Loureiro, 1997; Kotov et al., 2012), and a detailed redescription is required. Bearing in mind the non-cosmopolitanism concept (Frey, 1982) and the type locality of D. hamata in North America, specimens from South America may be a new taxon.

In the Neotropical region, D. hamata can be easily separated from $D$. leptorhyncha by the following characteristics: (1) the rostrum is longer in $D$. leptorhyncha (see Smirnov, 1996, figs. 309, 310; Van 
Damme and Dumont, 2010, fig. 9A) than in D. hamata (see Birge, 1879, fig. 13; Smirnov, 1996, fig. 296; Flössner, 2000, as Alonella hamulata (Birge, 1910), fig. 106A; present data, Fig. 3F); (2) seta III on the IDL of limb I is thicker in D. hamata (see Smirnov, 1996, fig. 300; Flössner, 2000, as Alonella hamulata, fig. 106G; present data, Fig. 4D, E) than in D. leptorhyncha (see Smirnov, 1996, fig. 319; Van Damme and Dumont, 2010, fig. 9f).

Distribution. It has a wide distribution and is a complex of species with, probably, local endemism. D. hamata has been reported in Afrotropical, Nearctic, Neotropical, Palaearctic, and Oriental regions (Kotov et al., 2013). Nevertheless, the Oriental population could be a new species (Sinev and Sanoamuang, 2011); therefore, further analysis of D. hamata is required.

Ecology. The surveyed area was dominated by Campsiandra comosa, which is one of the typical plants of the zone. Cladocerans were most numerous in habitats associated with the roots of plants. The water temperature during sampling was $30.2^{\circ} \mathrm{C}$, conductivity $6.7 \mu \mathrm{S} . \mathrm{cm}^{-1}$ value, $\mathrm{pH} 6.6$, and dissolved oxygen 8.2 $\mathrm{mg} / \mathrm{L}$.

\section{Discussion}

Following Kotov and Fuentes-Reinés (2015b), Sinev and Fuentes-Reinés (2016) and the information presented in this study, the total number of cladocerans for Colombia has increased to 105 valid species. Keeping in mind these new records, the number of species belonging to the genera Alona and Stroblocerus increased to eight and two, respectively, whereas the genus Disparalona is recorded for the first time from Colombia. In Colombia, the records of cladocerans in rivers are non-existent, which is probably due to insufficient efforts in cladoceran research, sampling difficulties, and taxonomical problems. This is in contrast to Brazil and Argentina, where some studies on cladoceran fauna have been carried out in a riverine environment (Paggi, 1992; Serafim Jr. et al., 2003; Serafim-Júnior et al., 2006; Sousa and ElmoorLoureiro, 2012). Hitherto, we recorded five new species from the Vichada Department and three from Colombia (see Tab. 1). The richness and abundance of microcrustacean taxa were lower than expected, probably because the samples were taken only from a small part of the river and did not reach rare species. In Chydoridae and Macrothricidae, the richness is always influenced by rare species, but on the other hand only one substrate (roots of Campsiandra comosa) was sampled. Most cladocerans, especially the family Chydoridae, are associated with macrophytes (FuentesReinés et al., 2012). We expect that this manuscript will motivate an increase in the studies on riverine cladoceran fauna, supported by a strong taxonomic base, leading to new records and, consequently, to a better comprehension of the Colombian diversity of freshwater microcrustaceans.

\section{ACKNOWLeDgements}

We are very grateful to Dr. Carlos A. Lasso Alcalá (Programa Ciencias Básicas de la Biodiversidad, Instituto de Investigación de Recursos Biológicos Alexander von Humboldt) for his help in field work. We also thank to Ms. Susan Casament for reviewing the final English manuscript. This study was financially supported by the Instituto de Investigación de Recursos Biológicos Alexander von Humboldt and COLCIENCIAS.

\section{RefERENCES}

Alonso, M. 1996. Crustacea, Branchiopoda. p. 1-486. In: M.A. Ramos et al. (eds), Fauna Ibérica, Vol. 7. Madrid, Museo Nacional de Ciencias Naturales, CSIC.

Álvarez, J. 2010. Caracterización de las ciénagas de Arcial, Porro y Cintura (rio San Jorge) y de Bano Charco Pescao y Pantano Bonito (Rio Sinú, departamento de Córdoba). p. 509-558. In: J.O. Rangel (ed), Colombia, diversidad biótica IX, Ciénaga de Córdoba: Biodiversidad, ecología y manejo ambiental. Bogotá, Universidad Nacional de Colombia.

Baird, W. 1843. The Natural History of the British Entomostraca. The Annals and Magazine of Natural History, 68: 81-95.

Barón-Rodríguez, M.; Gavilán, R. and Ramírez, J.J. 2006. Variabilidad espacial y temporal en la comunidad de cladóceros de la Ciénaga de Paredes (Santander, Colombia) a lo largo de un ciclo anual. Limnética, 25: 624-635.

Birge, E.A. 1879. Notes on Cladocera. Transactions of the Wisconsin Academy of Sciences, Arts and Letters, 4: 77-109.

Birge, E.A. 1910. Notes on Cladocera. IV. Transactions of the Wisconsin Academy of Sciences, Arts and Letters, 16: 1017-1066.

Brady, G.S. 1904. On Entomostraca collected in Natal by Mr. James Gibson. Proceedings of the Zoological Society of London, 1904: 121-128.

Chian, S.C. and Du, N.S. 1979. Fauna Sinica: Crustacea: Freshwater Cladocera. Beijing, Science Press, 297p. [Chinese]

Daday, E. 1905. Untersuchungen über die Süsswasser-Mikrofauna Paraguays. Zoologica, 18(44): 1-375. 
Delachaux, T. 1918. Cladocères des Andes péruviennes. Bulletin de la Société neuchâteloise des sciences naturelles, 43: 18-33.

Dumont, H.J. and Silva-Briano, M. 1998. A reclassification of the anomopod families Macrothricidae and Chydoridae, with the creation of a new suborder, the Radopoda (Crustacea: Branchiopoda). Hydrobiologia, 384: 119-149.

Dybowski, B. and Grochowski, M. 1894. O Lynceidach czyli Tonewkach fauny krajowej. Kosmos Seria a Biologia (Warsaw), 19: 376-383.

Elmoor-Loureiro, L.M.A. 1997. Manual de identificação de cladóceros límnicos do Brasil. Brasília, Universa - Universidade Católica de Brasília, 156p.

Elmoor-Loureiro, L.M.A. 2007. Phytophilous cladocerans (Crustacea, Anomopoda and Ctenopoda) from Paraná River Valley, Goiás, Brazil. Revista brasileira de Zoologia, 24: 344-352.

Flössner, D. 2000. Die Haplopoda und Cladocera (ohne Bosminidae) Mitteleuropas. Leiden, Backhuys Publishers, 428p.

Frey, D.G. 1967. Phylogenetic relationships in the family Chydoridae (Cladocera). Marine Biology Association of India, Proceedings of the International Symposium on Crustacea, 12-15 January 1965, Part 1: 29-37.

Frey, D.G. 1982. Questions concerning cosmopolitanism in Cladocera. Archiv fur Hydrobiologie, 93: 484-502.

Fryer, G. 1968. Evolution and adaptive radiation in the Chydoridae (Crustacea: Cladocera): a study in comparative functional morphology and ecology. Philosophical Transactions of the Royal Society of London, B: Biological Sciences, 254: 221-385.

Fuentes-Reinés, J.M. 2014a. New records of Cladocera (Crustacea: Anomopoda) from Laguna Navío Quebrado, La Guajira Department, Colombia. Nauplius, 22: 21-32.

Fuentes-Reinés, J.M. 2014b. Leydigia (Neoleydigia) cf. striata Birabén, 1939 (Crustacea: Cladocera: Chydoridae) from Colombia and its differentiation from $L$. (N.) cf. ipojucae (Brehm, 1938). Nauplius, 22: 67-73.

Fuentes-Reinés, J.M. 2014c. Presence of Diaphanosoma spinulosum Herbst, 1975 (Crustacea: Cladocera: Ctenopoda, Sididae) in a coastal system of northern Colombia, with comments on D. birgei Kořínek, 1981. Boletín de investigaciones marinas $y$ costeras, 43: 407-413.

Fuentes-Reinés, J.M. 2015. First record of Parvalona parva (Daday, 1905) (Crustacea: Anomopoda: Chydoridae) from Colombia. Check List, 11: 1691-1695.

Fuentes-Reinés, J.M. and Elmoor-Loureiro, L.M.A. 2011. Occurrence of Guernella raphaelis Richard, 1892 (Crustacea: Cladocera:Macrothricidae) in Cienaga Grande de Santa Marta, Colombia. Check List: 817-819.

Fuentes-Reinés, J.M. and Elmoor-Loureiro, L.M.A. 2015 a. Annotated checklist and new records of Cladocera from the Ciénaga El Convento, Atlántico-Colombia. Pan-American Journal of Aquatic Sciences, 10: 189-202.

Fuentes-Reinés, J.M. and Elmoor-Loureiro, L.M.A. 2015b. First record of Karualona penuelasi (Cladocera: Anomopoda: Chydoridae) from Colombia. Revista Mexicana de Biodiversidad, 86: 1091-1094.

Fuentes-Reinés, J.M. and Zoppi de Roa, E. 2013. New additions to the cladoceran fauna of Ciénaga Grande de Santa Marta and Colombia. Check List, 9: 9-24.
Fuentes-Reinés, J.M.; Zoppi de Roa, E.; Morón, E.; Gámez, D. and López, C. 2012. Conocimiento de la fauna de Cladocera (Crustacea: Branchiopoda) de la Ciénaga Grande de Santa Marta, Colombia. Boletín de Investigaciones Marinas y Costeras, 41: 121-164.

Garfias-Espejo, T. and Elías-Gutiérrez, M. 2003. Taxonomy and distribution of Macrothricidae (Crustacea: Anomopoda) in southeastern Mexico, northern Guatemala and Belize. Anales del Instituto de Biología, 74: 105-134.

King, R. 1853. On Australian Entomostraca. Papers and Proceedings of the Royal Society of Tasmania, 2: 253-263.

Kotov, A.A.; Forró, L.; Korovchinsky, N.M. and Petrusek, A. 2013. World checklist of freshwater Cladocera species. Available at http://fada.biodiversity.be/group/show/17. Accessed on 11 May 2017.

Kotov, A.A. and Fuentes-Reinés, J.M. 2015a. A new species of Leberis Smirnov, 1989 (Cladocera: Chydoridae) from Colombia. Zootaxa, 3957: 553-566.

Kotov A.A. and Fuentes-Reinés, J.M. 2015b. An annotated checklist of the Cladocera (Crustacea: Branchiopoda) of Colombia. Zootaxa, 4044: 493-510.

Kotov, A.A. and Fuentes-Reinés, J.M. 2014. A new species of Leydigia Kurz, 1875 (Cladocera: Chydoridae) from Colombia. Zootaxa, 3814: 399-408.

Kotov, A.A.; Jeong, H.J. and Lee, W. 2012. Cladocera (Crustacea: Branchiopoda) of the south-east of the Korean Peninsula, with twenty new records for Korea. Zootaxa, 3368: 50-90.

Norman, A.M. and Brady, G.S. 1867. A monograph of the British Entomostraca belonging to the families Bosminidae, Macrothricidae and Lynceidae. Natural History Transactions of Northumberland and Durham, 1: 354-408.

Paggi, J.C. 1992. A new species of Ilyocryptus (Anomopoda: Macrothricidae) from Argentina. Hydrobiologia, 231:141-151.

Rey, J. and Vasquez, E. 1986. Cladocères de quelques corps d'eaux du bassin moyen de l'Orénoque (Venezuela). Annales de Limnologie, 22: 137-168.

Richard, J. 1897. Entomostracés de l'Amerique du Sud, recueillis par MM. U. Deiters, H. von Ihering, G.W. Müller et C.O. Poppe. Mémoires de la Société Zoologique de France, 10: 263301.

Sars, G.O. 1862. Hr. studios. Medic. G.O. Sars fortsatte sit Foredrag over de af ham i Omegnen af Christiania iagttagne Crustacea cladocera. (Mr. Medical student G.O. Sars continued his presentation about the Crustacea cladocera he collected in the vicinity of Christiania). Forhandlinger $i$ Videnskabs-Selskabet i Christiania, 1861: 250-302.

Sars, G.O. 1901. Contributions to the knowledge of the freshwater Entomostraca of South America, as shown by artificial hatching from dried material. 1. Cladocera. Archiv for Mathematik og Naturvidenskab Christiania, 23: 1-102.

Serafim Jr., M.; Lansac-Tôha, F.A.; Paggi, J.C.; Velho, L.F.M. and Robertson, B. 2003. Cladocera fauna composition in a riverlagoon system of the upper Paraná River floodplain, with a new record for Brazil. Brazilian Journal of Biology, 63: 349-356.

Serafim-Júnior, M.; Perbiche-Neves, G; Brito L. and Ghidini, A.R. 2006. Zooplâncton do rio Itajaí-Açú a jusante da cidade de Blumenau, Santa Catarina, Brasil. Estudos de Biologia, 28: 41-50. 
Sinev, A.Y. and Fuentes-Reinés, J.M. 2016. A new subspecies of Ovalona setulosa (Megard, 1967) (Cladocera: Anomopoda: Chydoridae) from the Caribbean coast of Colombia. Zootaxa, 4121: 49-58.

Sinev, A.Y. and Sanoamuang, L. 2011. Hormonal induction of males as a method for studying tropical cladocerans: description of males of four chydorid species (Cladocera: Anomopoda: Chydoridae). Zootaxa, 2826: 45-56.

Smirnov, N.N. 1992. The Macrothricidae of the world. Guides to the identification of the microinvertebrates of the continental waters of the world. Vol. 1. Amsterdam. The Hague, SPB Academic Publishing, 143p.

Smirnov, N.N. 1996. Cladocera: the Chydorinae and Sayciinae (Chydoridae) of the world. Guides to the identification of the microinvertebrates of the continental waters of the world. Vol. 11. Amsterdam. The Hague, SPB Academic Publishing, 197p.
Sousa, F.D.R. and Elmoor-Loureiro, L.M.A. 2012. How many species of cladocerans (Crustacea, Branchiopoda) are found in Brazilian Federal District? Acta Limnologica Brasiliensia, 24: 351-362.

Sousa, F.D.R.; Elmoor-Loureiro, L.M.A. and Santos, S. 2016. New findings of Hexalona-branch representatives in Brazil, with a description of Prenda gen. nov. (Crustacea: Anomopoda: Aloninae). Journal of Natural History, 50: 1-42.

Stingelin, T. 1906. Cladoceren aus Paraguay. Zweiter Beitrag zur Kenntnis südamerikanischer Entomostraken. Annales de Biologie Lacustre, 1: 1-12.

Van Damme, K. and Dumont, H.J. 2010. Cladocera of the Lençóis Maranhenses (NE - Brazil): faunal composition and a reappraisal of Sars' Method. Brazilian Journal of Biology, 70: 755-779.

Zoppi de Roa, E. and Vázquez, W. 1991. Additional records for Mantecal and new for Venezuela. Hydrobiologia, 225: 45-62. 